\title{
Pathophysiology and modern treatment of ulcer disease (Review)
}

\author{
G.E. HOLLE \\ Gastrointestinal Research Laboratory, University Policlinic, \\ Pettenkoferstrasse 8a, D-80336 Munich, Germany
}

Received October 12, 2009; Accepted December 1, 2009

DOI: 10.3892/ijmm_00000368

\begin{abstract}
This is an overview of the pathophysiological abnormalities of gastroduodenal (GD) ulcers [duodenal ulcer (DU), gastric ulcer (GU) and Dragstedt ulcers (combined DU and GD)], as well as the effects of the different treatments (surgical, medicinal and physiological) described since the introduction of stomach resections. The intention is to demonstrate whether the peptic ulcer diseases are a homogeneous entity with a characteristic pathophysiology or whether they represent the final expression of many heterogeneous causes including impairment of upper gastrointestinal motility. The review also asks whether DU and GU have a common or different pathogenesis and whether ulcers in the stomach might be predominantly due to impaired mucosal resistance and the DU to gastric hypersecretion. The symptoms of both diseases are also compared with the findings in the normal controls.
\end{abstract}

\section{Contents}

1. Introduction

2. Antacids

3. Pirenzepine

4. Histamine $\mathrm{H}_{2}$-receptor antagonists

5. Helicobacter pylori

6. SPV and pyroloplasty

\section{Introduction}

In recent years the hospitalization rate for duodenal ulcer (DU) has decreased by $43 \%$, that for gastric ulcer (GU) by $8 \%$ and mortality by ca. $62 \%$. At first sight these figures might suggest that the disease as such is dying out. This is an

Correspondence to: Dr G.E. Holle, Gastrointestinal Reseach Laboratory, University Policlinic, Petterkoferstasse 8a, D-80336 Munich, Germany

E-mail: hollegresearch@aol.com

Key words: duodenal ulcer, gastric ulcer, Dragstedt ulcers illusion based to some extent on improvements in diagnosis, therapy and control of complications (1).

Direct incidence studies in the USA and Denmark show that ulcer occurrence is unchanged, i.e., $10 \%$ of men and ca. $5 \%$ of women in the Caucasian western population are expected to have some form of ulcer disease during their lifetime. This unchanged trend is genetically programmed: 30$59 \%$ of ulcer patients have a positive family history in contrast to $5-15 \%$ of control persons (2-5). DU and GU follow separate genetic pathways. We owe this information almost entirely to the teams attached to the Center for Ulcer Research and Education of the University of California, Los Angeles, CA (1). Irrespective of the nature of the triggering noxa the leading symptom of ulcer disease, the lesions of the mucosa, is always preceded by a change in the permeability of the mucosal epithelium, which, with a lowering of the transepithelial electric potential difference (PD) and resistance $(\mathrm{R})$, allows re-diffusion of $\mathrm{H}^{+}$ions in damaging concentration. The extent and course of the lesions are linear functions of the concentration and duration of the noxious effect $(4,5)$.

In 1977 Silen (6), showed that the instillation of $120 \mathrm{mM}$ acid over $30 \mathrm{~min}$ or a $\mathrm{pH}$ of 2.25 for $6 \mathrm{~h}$ in the gastrointestinal lumen led in $100 \%$ of tests to serious exulceration. The same amount of acid produced by stimulation led to an exulceration rate of only $10 \%$. Silen compared the first trial condition to the interdigestive motility state in DU (7). This suggests that in ulcer disease several factors have to occur together in order to trigger a recurrence of the peptic lesion. On the one hand there are aggresors such as pepsin and acid, on the other the mucosal resistance (8). Equally important are the mechanisms that bring about the exposure necessary for damage to occur (9).

What are the changes brought about by stimulation that protect the gastric mucosa? It normally activates epithelial mucus and bicarbonate production. This is pronounced in ulcer patients, particularly in gastroduedenal (GD) type. However, in these patients the genetically induced changes in the gastrointestinal motility (9) and also the alterations in the chemical composition of the mucus with the increased lowmolecular glycoproteins are pathological (10), as proteolytic decomposition from the lumen and $\mathrm{H}^{+}$-ion rediffusion are favored.

Stimulation normally influences gastric blood flow. It is known that no necrosis develops when there is a 4 -fold 
increase in flow or when the mucous membrane is perfused with pure $\mathrm{O}^{2}(11)$. In comparison, when the mucosal blood flow is reduced subliminal noxae cause an increase in $\mathrm{H}^{+}$-ion rediffusion and extreme damage to the mucosa (11). There is, however, no ulcer without acid $(7,12,13)$. In DU and GU the lower limit of acid stimulation is $10 \mathrm{mEq} / \mathrm{h}$. Some $50-70 \%$ of DU are hyperacidic with a $50 \%$ increase in the maximal acid output MAO. The cephalic phase also brings an increase in secretion response of $50-70 \%$ (13).

Basal hypersecretion of $+110 \%$ is very important. There is no ulcer with basal achlorhydria. This, too, is hereditary, as is the hyperpepsinogenic production, which in both kinds of ulcers has a higher increase than the acid $(14,15)$, with stimulation over $100 \%$ compared to the norm (16). The hypersensitivity of the chief and mucous neck cells is reflected in the requirement of only one-third of the normal pentagastrin dose for half-maximal response (D50). For acid the D50 requires three quaters of the normal dose and is pathological in only a few patients, indicating that every case of hyperacidity is accompanied by greatly increased pepsin and that many normosecretors still have high levels of pepsin. In $60 \%$ of DU hyperpepsinogenemia I is also present, which correlates closely with the acidity and is of autosomal dominant inhertance in the majority of cases. Secretion behavior is not dependent on age, onset or duration of the illness, family history or the activity and progress of the ulcer.

It is widely accepted that the hypersecretion is caused by an increase in the mucosal capacity to secrete acid and pepsinogen $(17,18)$. Cox counted the parietal cells (PCs) in necropsy material and calculated this as 1.8 billion for the DU which represents a PC hyperplasia of $62 \%$. The cell count for the smaller GU is 0.8 billion. We were able to show $(19,20)$ that the density of the PC population is increased in both diseases: on average $+44 \%$ in $\mathrm{GU}$ and $+47 \%$ in DU, with hypersensitivity of pepsinogen and, to a lesser extent, acid production. Two factors play a role: enlargement of the secretory capacity and the numbers of the of PCs and chief cells with specific receptors, e.g., gastrin receptors (21-23), muscarinic-cholinergic receptors and receptors of the secretin group, e.g., VIP for pepsin (24). The basal serum gastrin levels are normal in ulcer patients. Possibly gastrin-17 has an effect here $(25,26)$.

We found that gastrin immunoreactive cells were within the normal range in the antrum of $96 \%$ of DU and $84 \%$ of GU patients before every therapy $(27,28)$. However, in some patients gastrin cells are hypersensitive to stimulants, particularly food.

In addition, in $70 \%$ of ulcer patients reduced inhibitory sensitivity of gastrin cells to luminal acid disturbs the autoregulation mechanism. This is particularly noticeable in the second part of the secretory response. In the majority of the patients this disturbance is also of autosomal dominant inheritance (5).

Chronic gastritis is a dynamic pathological process classified into three subtypes: A, B and AB. Type A also termed 'pernicious type', is an agetypical form with corpus gland atrophy and has autosomal dominant inheritance, as family history analyses show. In gastric carcinoma there are two genetically different etiopathological types. In carcinoma of the proximal stornach the gastrin cells are reduced by 20 $70 \%$ in the antrum and the 5-HT (serotonin) - i.r., cells are drastically increased by $200-400 \%$ (normal range, 0.25 $0.39 \%$ of the total cell count) (28).

In addition to the PC increase in the stornach fundus in peptic ulcer there is also a $20 \%$ reduction in the histaminestoring mast cells (29). Parallel to this, Lorenz et al demonstrated the reduction in histamine tissue and decreased histamine-methyltransferase activity (30).

Epidermal growth hormone, a natural cytoprotector, is secreted in large quantities in Brunner's glands and in salivary glands and their efferent ducts, is stable against all gastric juice proteolytic enzymes, and provides maximum stimulation for mucosal cell proliferation, while at the same time totally inhibiting acid secretion, irrespective of the kind of stimulation. It is the main physiological factor for restorative conservation of the epithelium. The same cells that produce epithelial growth hormone also synthesize the blood group antigen (31-33). Of the latter we know that in a high proportion of GU cases it is not produced at all. This is called 'nonsecretor status' and, like the established frequency of blood group 0 in DU, is a hereditary symptom (5). In spite of the morphological link between the two factors, pathological deviations in synthesis and function of epithelial growth hormone in ulcer disease are not yet fully ascertained, although the clinical dysfunction of this hormone, non-inhibition of acid, is evident.

Similar problems occur in connection with genetic dysfunction of the prostaglandins. We have long known that prostaglandin $\mathrm{E}_{1}$ (PGE) inhibits gastric acid secretion, stimulated by histamine, gastrin, 2-deoxyglucose, carbachol and food in the dog. The mechanism of this inhibition has not been fully elucidated, but activity against a wide range of stimulants indicates an action of mucosal blood flow $(32,33)$. Adenosin monophosphate (cyclic AMP) in contact with histamine may be involved. Despite this, it is believed that in ulcer pathogenesis prostaglandins act by regulating the blood flow. PGE reduces mucosal blood flow and inhibits acid secretion. Exogenically applied prostaglandins also do not confer cytoprotection, as Ito et al demonstrated (34). Genetic abnormalities are present in the transport functions of the upper gastrointestinal tract and pylorus $(35,36)$.

Accelerated stomach emptying in DU has long been known. Changes in the pylorus in many DU patients makes the extent of the autosomal dominant hereditary disturbance difficult to calculate. The underlying cause is loss of the vago-vagal duodeno-antral inhibitory reflex, which in healthy people is activated by acidification of the duodenum and leads to a temporary cessation of contractile antral motility. In DU patients this loss results in the overacidified stomach contents being propelled into the duodenum (37-39). Another faulty mechanism is found in the interdigestive motility of the upper gastrointestinal tract. In DU maximum acid secretion also occurs in the interdigestive phase at night as weIl as during the day. The propulsive phase II is greatly prolonged at the expense of the resting phase I of the interdigestive complex, and shows irregular, intensified contractions (40-42). The already overacidified fasting secretion is thus emptied almost throughout the interdigestive period into the bulbus duodeni, which has the motor function of a reservoir. A rise 


\section{Fundus Parietal-Cell-Mass and Serum Gastrin before and during. prolonged Administration of $\mathrm{H}_{2}$-receptor antagonists and Antacids}
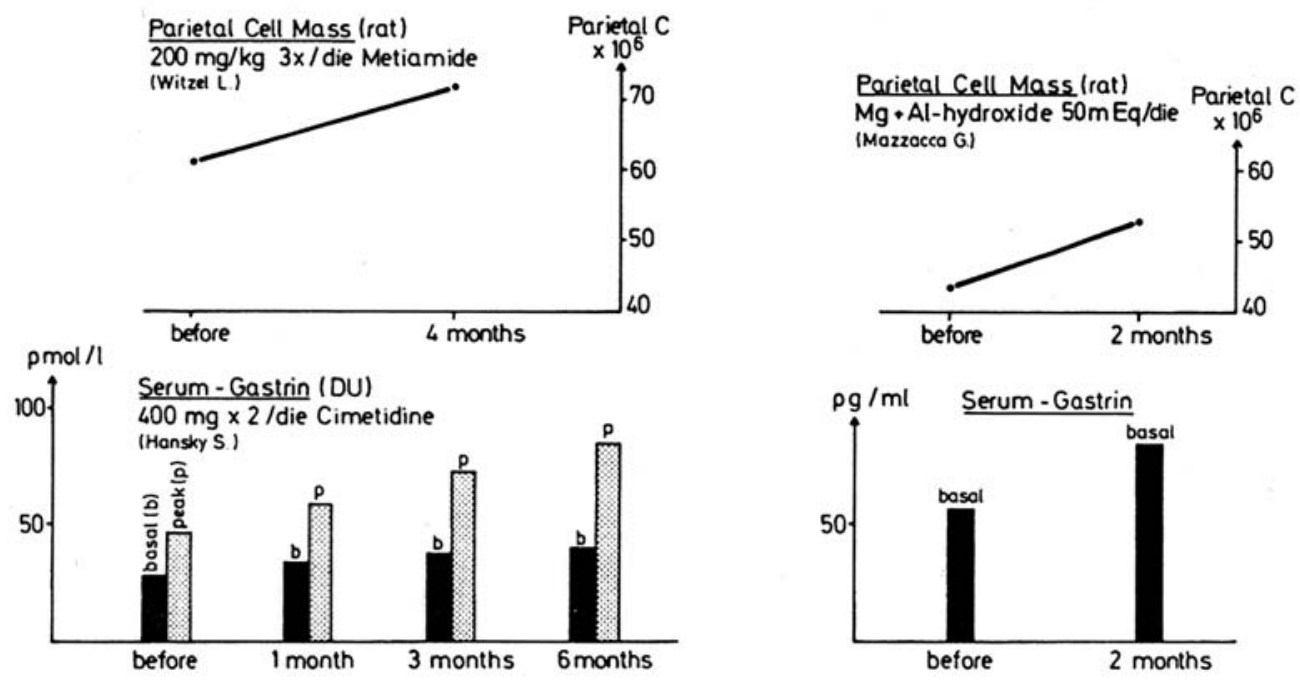

Figure 1. Fundus parietal cells combined with serum gastrin during prolonged medical administration: $\mathrm{H}_{2}$-antagonists (left side) and antacids (right side) (85-87).

in $\mathrm{pH}$ is only possible in the following short phase III (MMC, migrating motor complex). At the same time, in DU the retrograde contractile activity in the middle section of the duodenum is abnormal, as the retropulsive peristaisis type 2 waves (up to $5 \mathrm{mmHg}$ ) are greatly reduced $(41,42)$. This is precisely the motility that under normal conditions propels bicarbonate from the duodenum back into the bulbus, so neutralizing it. In DU the bulbus is permanently underneutralized in the entire fasting period, although secretin and bicarbonate production is inceased $(41,42)$.

In contrast, in $\mathrm{GU}$ the type 2 peristaltic waves in the middle duodenum are significantly increased. The intensified retrograde peristaisis with the weakened pyloric tone and reduced antral motility in UV leads to increased bilious and pancreatic reflux into the stomach (43). This, in association with the increased pepsin output has been postulated to be the key injurious factor causing gastric ulcer (43).

As seen from the multiple pathological symptoms in peptic ulcers, the disease is polygenetically programmed with inborn errors in the innervation of the gastrointestinal tract, where mucosal protection is also locally weakened and the stomach secretion faulty. Whatever form it takes, treatment must therefore be symptomatic, whereby precedence must be given to the best method of controlling the cardinal symptoms. In this disease not only are individual functions disturbed but they are also wrongly coordinated, and the system is incorrectly programmed, resulting in physiologically inappropriate patterns of secretion and motility. If one defect, e.g., gastric hypersecretion is corrected, the system spontaneously tries to compensate this, e.g., by continuously increasing G-cell mass over the years (Fig. 1).

The ultimate goals of peptic ulcer treatment are elimination of pain, healing of ulceration (mucosal inflammation and heartburn) and prevention of ulcer recurrence. Pharmacological intervention has been mainly directed at the suppression of peptic acid activity. Serious attempts have also recently been made to develop drugs to enhance mucosal resistance and to try to eliminate bacteria.

\section{Antacids}

Antacids - the first such agents were antacids (44-46). Postprandial acid output after antacid ingestion was significantly increased by an average of $16 \%$; the level of gastric juice also rose (46). Other side effects were increase in gastrin release, gastric secretion, gastric emptying rate and duodenal acid load. Twenty-five percent of patients suffered from diarrhea, some from duodenogastric reflux (47-49). Multiple receptors showed interactions: $\mathrm{H}_{2}$ receptor, gastrin and acetylcholine receptor and carbamyl-choline interact (49) and seem to sensitize cells like gastrin cells (Fig. 1). The goal of antacid treatment is to raise the $\mathrm{pH}$ to 3.0 as gastric content end-point, to reduce the load of acid delivered into the duodenum, and to reduce pepsin activity by lowering conversion of pepsinogen into pepsin. The bile-acid-binding properties in the duodenum increase gastric reflux and play a pathogenic role in GU. The four types of antacids: calcium, carbonate, and magnesium and aluminium hydroxide all require evaluation of the speed with which an antacid combines with acid. Alteration in bowel movement is frequently combined with constipation.

\section{Pirenzepine}

Anticholinergics (pirenzepine) $(22,50)$. Based on the role of the vagus nerve in stimulating acid and pepsin secretion mediated by acetylcholine (51), pirenzepine a benzodiazepine with structural similarities to tricyclic compounds, but without activity on the central nervous system, was developed as a drug against peptic ulcer disease. Mucosal permeability to hydrogen ions and the gastric mucosal barrier are not affected by anticholinergic drugs (e.g., atropine). 
Optimal dosage of pirenzepine inhibits basal and pentagastrin-stimulated gastric acid secetion by decreasing the total volume of secretion but with little change in the $\mathrm{pH}$. Basal and nocturnal acid output are reduced by $40-50 \%$ and maximal acid output by $30-40 \%$ (52). A high dose is required to produce a significant delay in gastric emptying. Endogenous gastrin release in response to a meal is slightly increased by anticholinergics. This effect is not observed if the $\mathrm{pH}$ is maintained at a constant level. The bile-acid binding properties in the duodenum increase gastric reflux and play a pathogenic role in GU. After cessation of the treatment, gastric secretion returns to a control level after $48 \mathrm{~h}$ (53).

\section{Histamine $\mathrm{H}_{2}$-receptor antagonists}

Cimetidine (54-56). This drug is equally effective against stimulation of acid output by histamine, pentagastrin and insulin. Pepsin output is reduced secondarily to reduction of volume and to reduction in acid. Both are similarly effective in GD and DU. Cimetidine is independent of or less sensitive to histamine. Gastrin release is enhanced during prolonged treatment and chronic $\mathrm{pH}$ changes. A dose of $300 \mathrm{mg}$ reduced nocturnal acid output by about $80-90 \%$ for as long as $7 \mathrm{~h}$ (57-59). After long-term treatment with cimetidine there is an increase in antral $\mathrm{pH}$ and inhibition of acid feedback on gastrin release, and an increase in parietal cell hyperplasia. $\mathrm{H}_{2}$-receptor antagonists increase transmucosal potential difference without affecting active transport of sodium or chloride $(60,61)$.

At a very early date Domschke et al $(62,63)$ described a drug called ranitidine. Ranitidine does not contain the imidazole nucleus of histamine, which was previously regarded as essential for the effect. The reduction of pepsin output is proportional to the reduction in gastric volume, as with cimetidine, but the action lasts longer than that of cimetidine.

Cimetidine $1.5 \mu \mathrm{g} / \mathrm{kg} / \mathrm{h}$ intravenously and $100 \mathrm{mg} / \mathrm{h}$ in the second hour brings down basal acid-secretion to $\sim 0$. Bloodflow in the mucosa is reduced and pepsin significantly decreased.

Cimetidine is equally effective applied orally and absorbed from the small intestine $(73 \%)$ with a peak blood level after $60-90 \mathrm{~min}$. Acid output is reduced for $7 \mathrm{~h}$ by $300 \mathrm{mg}$ nocturnal application.

\section{Helicobacter pylori}

Several years ago interest was centered on a spiral gramnegative bacterium. It has unique cellular fatty acid output and an ultrastructure different from other campylobacters (64). It colonizes the mucosa of the upper gastrointestinal tract of $>84 \%$ of the human population. This bacterium was named Helicobacter pylori because it is also observed in the minority of people suffering from peptic ulcer disease with inflammation of the duodenal and gastric mucosa which predisposes to peptic ulceration at those sites, produces powered urease enzymes, which tolerate acid secretion, and large amounts of extracellular catalase. It is also believed to cause metaplasia in gastritis and implies a high risk for gastric cancer (65-68).

The majority of the Helicobacter pylori bacteria live freely in colonized hosts, but $\sim 20 \%$ are believed to bind gastric epithelial cells. This colonization is highly specific in vivo when it overlays islands of gastric metaplasia (69). The interaction of these bacteria with the epithelial cells plays an important role in the pathogenesis of cancer risk. Loci have been identified the mucosa in which people harboring particular alleles which have different risk of disease, and Helicobacter pylori should have the capacity to interact with those molecules that induce epithelial response with carcinogenic potential. Helicobacter pylori is well characterized as determining the 'cag' pathogenicity island (cag PAI), a multigene locus.

It induces gastritis augmenting the risk for atrophie gastritis and distal gastric cancer. In most people, however, it remains asymptomatic. It would be useful to identify a few people with high risk, because they could serve as a paradigm for the chronie role of inflammation in the genesis of malignancies that arise in the gastrointestinal tract.

Helicobacter pylori is not the only organism that is believed to cause active chronie gastritis in man. Other infections with spiral organisms have been described $(70,71)$. Antibody to Helicobacter pylori was measured by ELISA in sera of patients and in gastric biopsy specimens $(72,73)$. Colloidal bismuth subcitrate (CBS) combined with tinidazole in patients sensitive to nitroimidazole eradicates most Helicobacter pylori organisms. Ulcers recur less often than in patients who retain Helicobacter pylori in the upper gastrointestinal tract over 12 months. The US Food and Drug Administration has approved the first two combination therapies to eradicate Helicobacter (66) (Table I).

The bacillus is sensitive to penicillin, erythromycin, cephalosporins, gentamycin, tetracycline and bismuth citrate $(74,75)$. Ranitidine has been combined with bismuth citrate (RBC), clarithromycin or amoxycillin. In $70 \%$ of patients the peptic ulcer healed within 4 weeks, but only $41-48 \%$ of the Helicobacter organism were eradicated. In a randomized study of 900 patients with peptic complaints an average of $75 \%$ of those given the combination of omeprazole plus clarithromycin, had Helicobacter eradication, but at 6 months $30 \%$ in one study and $52 \%$ in another had ulcer recurrence. In a third study at final analyses after 4-6 weeks $50-70 \%$ of ulcers had not healed (66). In Germany, recently the therapy has consisted of a combination of pantoprazol for acidity and heartburn, amoxycillin and clarithromycin as antibiotics to eradicate the Helicobacter pylori. If the ulcer does not heal promptly, pantoprazol alone can be continued. The healing rate of around $40-50 \%$ in duodenal ulcers at 1 year after discontinuation of treatment is similar to that in all the conservative regimes.

The healing time may be shortened with multiple drug combinations and when Helicobacter pylori is completely eradicated. However, there is no influence with respect to peptic ulcer relapse or the different types of mucosal inflammation or recurrence. The side effects of combined drug regimens are those of all the individual drugs, but this topic is not discussed here. 


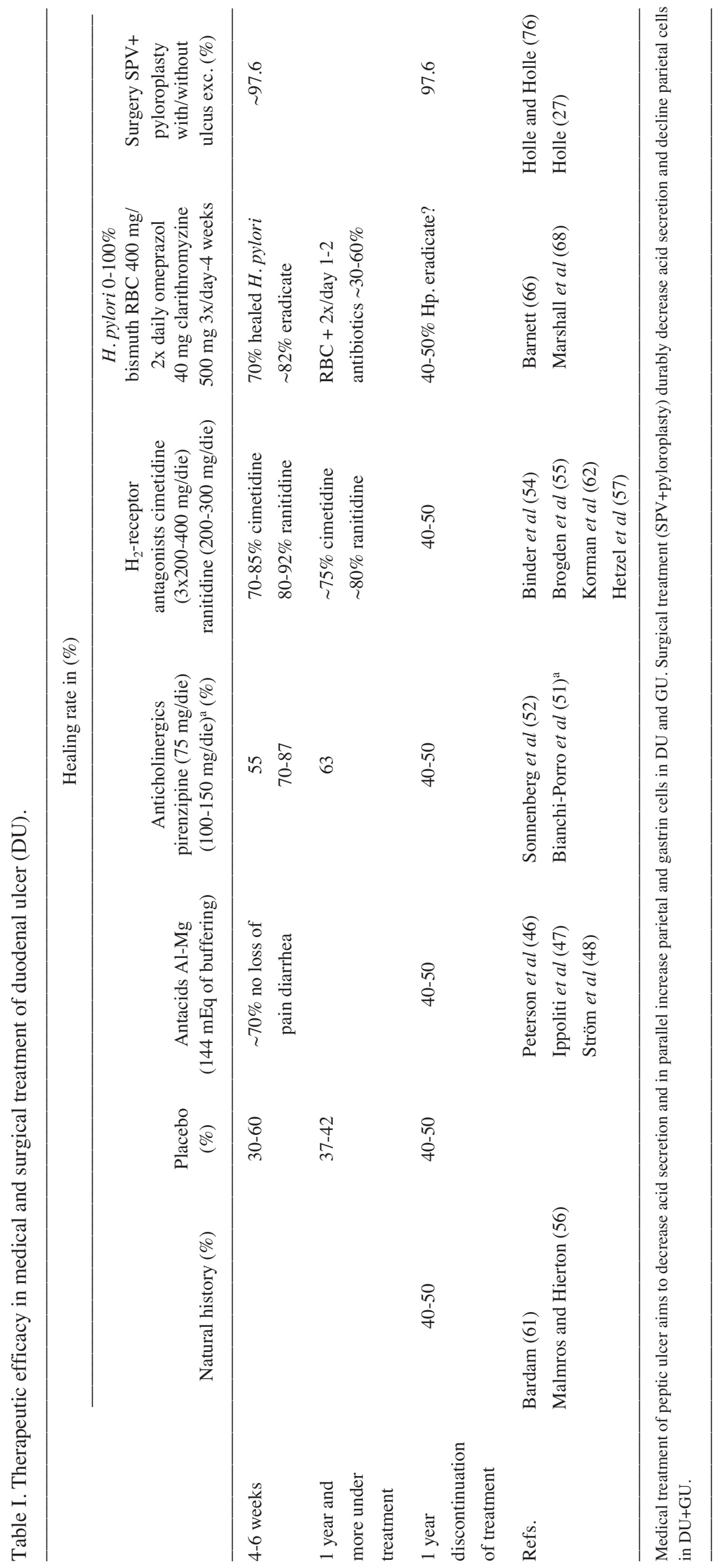


Cell Behavior in the Stomach pre and post SpV and Pyloroplasty

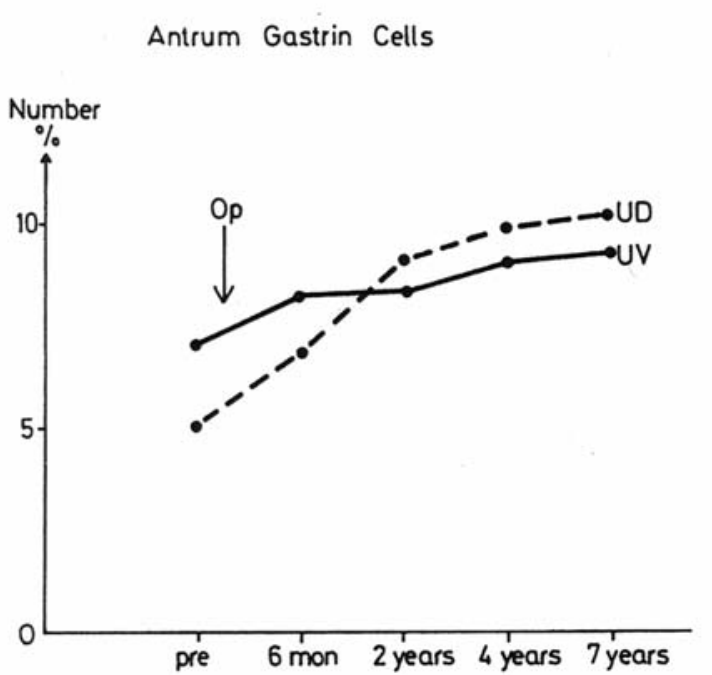

\section{Fundus Parietal Cells}

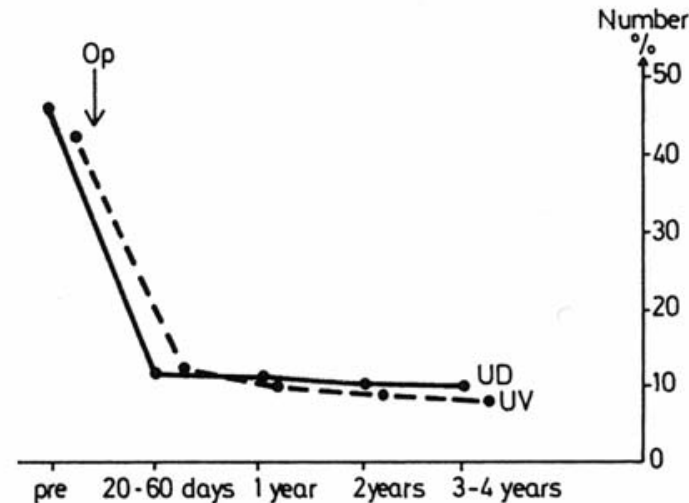

fundus in GU and DU.

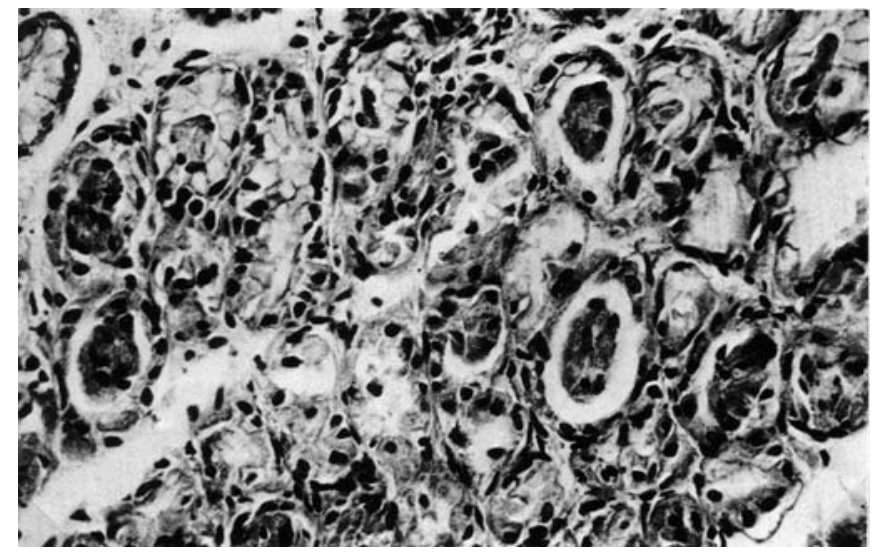

Figure 3. Parietal cell detritus and whole parietal cells in fundic glandular lumina in DU early after SPV and pyloroplastic. (Stain/HE).

\section{SPV and pyroloplasty}

Between 1964 and 1982 at Munich Surgical Clinic we treated 1407 duodenal and 308 gastric ulcers, by non-resecting means, with selective proximal vagotomy (SPV) and pyloroplasty of form and function either submucous or open or with resection, and if necessary, with ulcer excision (76). The following results were achieved over a period of 5-7 years postoperative1y by examination combined with endoscopy and biopsy from the fundus and antrum, preoperatively, and then postoperatively, at 11 days, 45 days and from then on annually. Clinically $89 \%$ of the patients showed reduction of the basal acid output (BAO) by $90 \%$, of maximal acid output (MAO) by $75 \%$, and a decrease in the mucosal postoperative diameter of $21 \%$ despite a significant increase in chief cells.

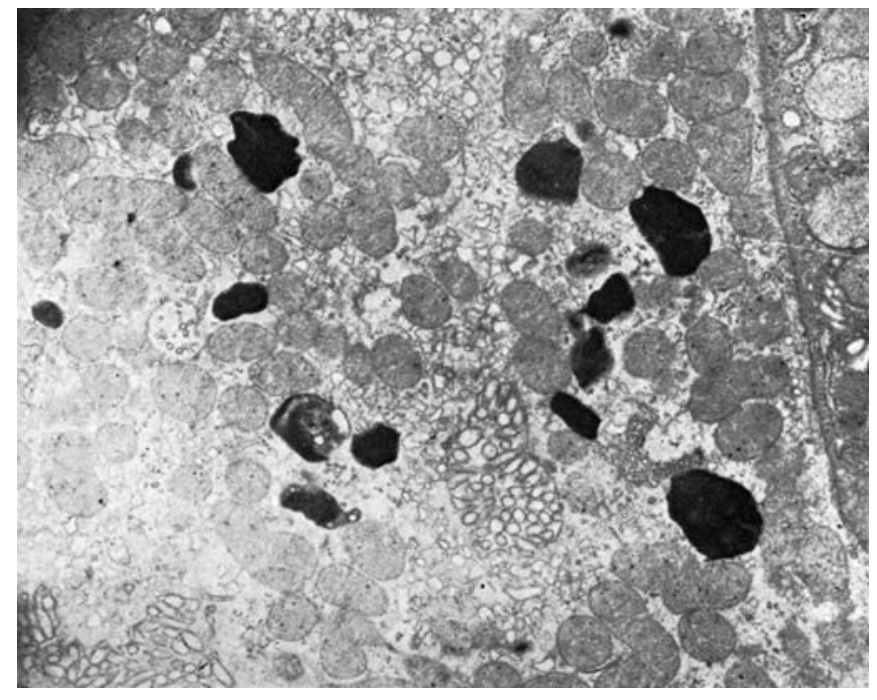

Figure 4. Parietal-cell with fat droplets in the degenerated cytoplasm in DU after SPV and pyloroplasty. (Prof. F. Miller, Inst. f. Zellbiol.).

There was amelioration of pain in $90 \%$ of cases, weight increase in $75 \%$ (from 1 to $15 \mathrm{~kg}$ ), dumping in $1.8 \%$, diarrhea in $2 \%$, recurrence in $2.7 \%$ of DU, and $7.3 \%$ of $\mathrm{GU}$, and mortality was $0.5 \%$ (76) (Fig. 2). Biopsy specimens from fundus and antrum mucosa were examined preoperatively and postoperatively $(77,78)$ : chief cells $(\mathrm{CH})$, parietal cells (PC), mucus neck cells (MNC), enterochromaffin cells (EC), gastrin cells (GC), and somatostatin i.r., D-cells (DC) were differentially stained and counted in the Leitz Ortholux II microprojector, outlined and determined in areas of a total of $\sim 8000$ gland cells $(24,27)$. The preoperatively increased PCs by $30-60 \%$ over normal levels, in peptic ulcers decreased in 
all cases postoperatively: in DU by $74.2 \%$ and in GU by $73.77 \%(19,20)$. The energy metabolism of the PC mitochondria, as measured by absorption photometry of succinate-dehydrogenase activity with TNBT (Nachlass), was also significantly reduced postoperatively (79). Early after operation, increased PC detritus and whole PC were seen in the lumen of the glands (Fig. 3) and fatty droplets, showing degeneration, were visible in the cell plasma on electronmicroscopy (Fig. 4). Accompaning our cell count results, Lehy et al $(80,81)$ investigated PC cell kinetics.

Following SPV and pyloroplasty the GC in the stomach antrum increased by up to $10 \%$ in DU and up to $16 \%$ in GU (Fig. 2), preoperative maximum $7 \%$ GC, and the peptic cells (chief cells and not MNC) in the stomach also increased continuously during the following years after surgery.

The inflammation seen preoperatively in the fundus ventriculi was not seen postoperatively in either DU or GU. The patients were mostly without drug medication postoperatively.

Despite the morphological changes after SPV plus pyloroplasty as sole treatment, the acid secretion remains greatly reduced over the following years, and the fate of recurrence of uncomplicated DU and GU is low at $2.4 \%$, over 4 years. Pharmacological intervention is usually not necessary. The complication rate of the SPV operation is zero. Motility disturbancies were without serious clinical signs (35). The outcome of this therapy depends on the skill of the surgeon.

Knowledge of the gastrointestinal system, particularly its innervation, has been greatly extended in recent decades and it has become clear that not only the vagus nerve and its sympathetic counterpart are responsible for the multiple deficiencies in motility and metabolism seen in peptic ulcer disease. These may also be triggered by extrinsic, intramural and serotoninergic, purinergic and various peptidergic transmitters (82). Together, these represent a kind of 'vegetative brain' (83), which regulates the gut functions. We do not know the underlying neurogenic causes of the frequent hereditary failures today, but they may extend back as far as to the neural crest (84). Our therapeutic efforts in the case of multifactorial polygenetic disorders, such as peptic ulcers, can only be directed against the various individual symptoms which are certainly not based on a simple infection which is expressed in the pathophysiology of the disease.

\section{Acknowledgements}

The studies were supported by the Deutsche Forschung Gemeinschaft (DFG): Ho 936/1-3; Ho 86/20-1 and the Bav. Ministry of Culture: Dr D. Bächler. I am indepted to Professor E. Wünsch, Professor W.G. Forsmann the assist, Drs U. Auerbach, J. Riedel and U.G. Höck, Nancy Cliff-N. for graphics and David Roseveare and Jennifer Grüner for translation checking.

\section{References}

1. Kurata JH, Honda DG and Frankl H: Hospitalisation, mortality rates for peptic ulcers: a comparison of a large health maintenance organisation and United States data. Gastroenterology 83: 1008-1015, 1982.
2. Rotter JL, Sones JQ, Samloff IM, Richardson CT, Gursky JM, Walsh JM and Rimoin DL: Duodenal-ulcer disease associated with elevated serum pepsinogen 1: an interested autosomal dominant disorder. N Engl J Med 300: 63-66, 1979.

3. Duplessis DJ: Pathogenesis of gastric ulceration. Lancet 1: 974, 1965.

4. Rotter JL and Rimoin DL: Peptic ulcer disease - a heterogeneous group of disorders. Gastroenterology 73: 604-607, 1977.

5. Johnson HD: Gastric ulcer: classification, blood group characterristic, secretion pattem and pathogenesis. Ann Surg 162: 996-1004, 1965.

6. Silen W: Founders lecture: new concept of the gastric mucosal barrier. Am J Surg 133: 8-12, 1977.

7. Smith P, O'Brien P, Fromm D and Silen W: Secretory state of gastric mucosa and resistence to injury by exogenic acid. Am J Surg 133: 81-85, 1977.

8. O'Brien P, Rosen S, Trencis-Buck L and Silen W: Distribution of carbonicanhydrase within the gastric mucosa. Gastroenterology 72 (5Pt1): 870-880, 1977.

9. Holle GE: Gastric reflex circuitry in the control of pyloric function and emptying: extrinsic and intrinsic pathways. In: Advances in the Innervation of the Gastrointestinal Tract. Holle GE and Wood JD (eds). Excerpta Medica 1008: 539-546, 1992.

10. Younan F, Pearson J, Allen A and Venables C: Changes in the structure of mucous gel on the mucosal surface of stomach in association with peptic ulcer disease. Gastroenterology 82: 827-831, 1981.

11. McGreevy JM and Moody FG: Prodection of gastric mucosa against aspirin-induced erosious by enhanced blood flow. Surg Forum 28: 357-359, 1977.

12. Dragstedt LR: Peptic ulcer: an abnormality in gastric secretion. Am J Surg 117: 143-152, 1969.

13. Baron JH: The relationship between basal and maximum acid output in normal subjects and patients with duodenal ulcer. Clin Sci 24: 357, 1963.

14. Bonfils S, Lewin M, Vatier J, Dubrasquet M and Bad JP: Correlation between acid and peptic secretion in man. (Coefficient K25) in the Physiology of Gatric Secretion. Semb LS and Myren J (eds). Universitets Forlaget Oslo, pp164, 1968.

15. Samloff IM, Liebman NM and Panitch NM: Serum group 1 pepsinogens by radioimmunoassay in control subjects and patients with peptic ulcer. Gastroenterology 69: 83-90, 1975.

16. Grossman MI: Neural and hormonal stimulation of gastric secretion of acid. Handbook Physiol 2 (Sec.6): 825-863, 1967.

17. Cox AJ: Stomach size and its relation to chronic peptic ulcer. Am Arch Pathol 54: 407-425, 1952.

18. Card WI and Marks IN: The relationship between the acid output of the stomach following maximal histamine stimulation and the parietal cell mass. Clin Sci 19: 147-163, 1960.

19. Holle GE, Schauer A and Fellner K: On the effect of selective proximale vagotomy on the parietal cells in duodenal ulcers. Chir Gastrointestinal 5: 310-317, 1971.

20. Holle GE, Fellner K and Schauer A: On the effect of selective proximal vagotomy on the parietal cells in gastric ulcers. Chir Gastroenter 7: 1-7, 1973.

21. Peitsch W: Gastrinreceptoren im Gastrointestinal trackt des Menschen Verhalten bei Carcinom und gastroduodeal ulcus. Z Gastroenterol 23: 10-14, 1985.

22. Von Zwieten PA and Schönbaum E: Modern develoments in cholinergic, muscarinercics, receptors and drugs. Vol 7. Progr Pharmacol Clin Pharmacol. Gustav Fischer Verlag, Stuttgart, 1989.

23. Tack JF, Janssens J and Vantrappen G: Characteristics of myerteric neurons in the gastric antrum and their receptor properties. In: Advances in the Innervation of the Gastrointestinal Tract. Holle GE and Wood JD (eds). Excerpta Medica 1008. Amsterdam, London, New York, pp169-180, 1992.

24. Holle GE, Dietl J and Demir I: Influence of the intramural innervation on the morphogenesis of the enteroendocrine cells and the genetic construct involved (Review). Int J Mol Med 11: 275-285, 2003.

25. Walsh JH and Grossman MI: Circulating gastrin in peptic ulcer disease. Mt Sinai J Med 4: 374, 1973.

26. Russell RCG, Bloom SR and Jones S: The interpretation of plasma gastrin - an explanation. Br J Surg 62: abs. 157, 1975.

27. Holle GE: Clinical aspects of the innervation of the gastrointestinal tract. J Auton Nerv Syst (Suppl): S501-S514, 1986. 
28. Holle GE, Stiegelmaier M, Riedel J, Ringel R, Siewert R, Eisenmenger $\mathrm{W}$ and Holle F: Histologie, immunochemical and morphometric study of the mucosa of the gastric antrum in patient with carcinoma of the stomach. Surg Gynecol Obstet 176: 65-72, 1993.

29. Räsanen T: Tissue eosinophils and mast cells in the human stomach wall in normal and pathological conditions. Acta Path Microbiol Scand (Suppl 12) 129: S1-S131, 1958.

30. Lorenz W, Troidl H, Barth H and Rohde H: Histamine, Magensekretion und peptisches Ulkus: Ein Versuch zur Erklärung spezieller Problem-und Irrtumsursachen bei klinischbiochemischen Untersuchungen. In: Cimetidine. Creutzfeldt W and Arnold R (eds). Excerpta Med 1016, Amsterdam, pp6-39, 1977.

31. Finke U, Rutten M, Murphy RA and Silen W: Effect of epidermal grows factor on acid secretion from guinea pig gastric mucosa: in vitro analysis. Gatroenterology 88 (5Pt1): 1175-1182, 1985.

32. Dousa TP and Dozois RR: Interrelationships between histamine, prostaglandins and cyclic AMP in gastric secretion: a hypothesis. Gastroenterology 73: 904, 1977.

33. Major IS and Scholes P: The localisation of a histamine $\mathrm{H}_{2}$ receptor adennylate cyclase system in canine parietal cells and its inhibition by prostaglandins. Agents Actions 8/4: 324-331, 1978.

34. Ito S, Lacy ER, Rutten MJ, Critchlow J and Silen W: Rapid repair of injured gastric mucosa. Scand J Gastroenterol (Suppl) 101: 87-95, 1984.

35. Reiser SB, Holle GE and Frey K: Motorische und electrische Aktivität der gastroduodenalen Übergangszone vor and nach selektiv proximaler Vagotomie allein und mit Pyloropkastik. Langenbecks Arch Chir (Suppl) pp249-245, 1982.

36. Valenzuela IE and Defilippi C: Pyloric sphincter studies in peptic ulcer patients. Am J Dig Dis 21: 229, 1976.

37. Johnson AG: Peptic ulcer and the pylorus. Lancet 1: 710-712 1979.

38. Thompson DG, Ritchie HD and Wingate DL: The effect of food on jejunal motor activity in normal subjects and in duodenal ulcer patients. Gastroenterology 78: abs. 1278, 1980.

39. Fischer RS and Cohen S: Pyloric sphincter dysfunction in patients with gastric ulcer. N Engl J Med 288: 273-275, 1973.

40. Grivel ML and Rückebusch Y: The propagation of segmental contractions along the small intestine. J Physiol 227: 611-625, 1987.

41. Borgström S and Arborelius M Jr: Duodenal motility pattern in duodenal ulcer disease. Scand J Gastroenterol 13: 349 , 1978 .

42. Archambault AP, Rovelstad RA and Carlson HHC: In situ pH of duodenal bulb contents in normal and duodenal ulcer subjects. Gastroentrology 52: 940-947, 1967

43. Flint FJ and Grech P: Pyloric regurgitation and gastric ulcer. Gut 22: 735-737, 1970.

44. Malagelada JR and Carlson GL: Antacid therapy. Scan J Gastroenterology (Suppl) 55: 67, 1979.

45. Grossman MI: Duration of action of antacids. Am J Dig Dis 1: $453,1956$.

46. Peterson WL, Sturdevant RAL, Frankl HD, et al: Healing of duodenal ulcer with an antacid regime. N Engl J Med 297: 341-345, 1977

47. Ippoliti AF, Sturdevant RAL, Isenberg JI, Binder M, et al: Cimetidine versus intensive antacid therapy for duodenal ulcer. Gastroenterology 74: 393, 1978.

48. Ström M, Gotthard R, Brodemar G and Walan A: Antacid/ anticholinergic cimetidine and placebo in treatment of active peptic ulcers. Scan J Gastroenterol 16: 599-602, 1981

49. Hurwitz A, Robinson RG, Vats TS, Whittier FC and Herrin WF: Effects of antacids on gastric emptying. Gastroenterology 71 : $268,1976$.

50. Hammer R: Subclass of muscarinic recepters and pirenzipine. Further experimental evidence. Scan J Gastroenterol (Suppl) 72: 59-67, 1982.

51. Bianchi-Porro G, Dal Monte PR, Petrillo M, Giuliani Picarri G, et al: Pirenzipine versus cimetidine in the duodenal ulcer. A double blind placebo controlled short term clinical trial. Digestion 23: 110, 1982.

52. Sonnenberg A, Müller-Lissner SA, Vogel E, Schmid P, Convers JI, Peter P, et al: Predictors of duodenal ulcer healing and relapse. Gastroenterology 81: 1061-1067, 1981.
53. Sun DCH and Shay H: Optimal effective dose of anticholinergic drug in peptic ulcer therapy. Arch Intern Med 97: 442-452, 1956.

54. Binder HJ, Cocco A, Crossley RJ, et al: Cimetidine in the treatment of duodenal ulcer. A multicenter double blind study. Gastroenterology 74: 380-388, 1971.

55. Brogden RN, Heel RC and Speight TM: Cimetidine: a review of its pharmalogical properties and therapeutic efficacy in peptic ulcer disease. Drugs 15: 93-131, 1978.

56. Malmros $\mathrm{H}$ and Hierton T: A postinvestigation of 687 medical treated cases of peptic ulcer. Acta Med Scand 133: 229 , 1949.

57. Hetzel DJ, Hecker R and Shaerman DJC: Longterm treatment of duodenal ulcer with cimetidine. Med J Aust 2: 612-614, 1980.

58. Black JW, Duncan WAM, Durant CJ, Ganellin CR and Parsons EM: Definition and antagonism of histamine $\mathrm{H}_{2-}$ receptors. Nature 236: 385, 1972.

59. Ivery KJ and Mackercher PA: Effect of cimetidine on ion fluxes and potential differences across the human stomach. Gut 19: 414-418, 1978.

60. Longstreth GF, Go VLW and Malagelada JR: Cimetidine suppression of nocturnal gastric secretion in active duodenal ulcer. N Engl J Med 294: 801, 1976.

61. Bardam KD: Intermittent treatment of duodenal ulcer with cimetidine. Br Med J 281: 20-30, 1980

62. Korman MG, Hanski J, Merrett AC and Schmitt GC: Ranitidine in duodenal ulcer. Incidence of healing and effect of smoking. Dic Dis Sci 27: 712, 1982

63. Domschke E, Sux G and Domschke W: Effect of ranetidine on pentagastrin induced gastric secretion of pepsin and $\mathrm{N}$-acetylneuranimic acid in man. Gastroenterology 78: abs. 1158, 1980.

64. Goodwin CS, Armstrong JA and Marshall BC: Campylobacter pyloridis in gastritis and peptic ulteration. Clin Pathol 39: 353-365, 1986

65. Marshall BJ, Barrett LJ, McCallum RW and Guerrant RL: Urea protect Helicobacter (Campylobacter) pylori from bactericidal effect of acid. Gastroenterology 59: 697-702, 1990.

66. Bamett AA: FAD reluctant about new pylori regimes. Lancet 346: $1697,1995$.

67. Frierson HF Jr, Caldwell SH and Marshall BJ: Duodenal bulb biopsy findings for patients with non-ulcer dyspepsia with or without Campylobacter pylori gastritis. Mod Pathol J 3: 271-276, 1990.

68. Marshall BJ, Warren JR and Goodwin CS: Duodenal ulcer relaps after eradication of Campylobacter pylori. Lancet 15: 836-837, 1989.

69. Peek RM Jr and Crabtree JE: Helicobacter infection and gastric neoplasia. J Pathol 208: 233-248, 2006

70. Dye KR, Marshall JB, Frierson HF, Guerrant RL and McCallum RW: Ultrastructure of another spiral organism associated with human gastritis. Dig Dis Sci 34: 1787-1791, 1989.

71. Marshall BJ and Warren JR: Unidentified curved bacilli in the stomach of patients with gastritis and peptic ulceration. Lancet 16: 1311-1315, 1984

72. Patel P, Khulusi S, Mendall MA, Lloyd R, Jazrawi R, Maxwell JD and Northfield TC: Prospective screening of peptic patients by Helicobacter pylori serology. Lancet 346: 1315-1318, 1995.

73. Israel DA and Peek RM Jr: The role of persistence in Helicobacter pylori pathogenesis. Curr Opin Gastroenterol 22: 3-7, 2006.

74. Marshall BJ, Armstrong JA, Francis GJ, Nokes N, Cam T and Wee SH: Antibacterial action of bismuth in relation to Helicobacter pylori colonisation and gastritis. Digestion 37 (Suppl. 2): S16-S30, 1987.

75. Marshall BJ: Campylobacter pylori: its link to gastritis and peptic ulcer. Rev Infect Dis 12 (Suppl. 1): S87-S93, 1990.

76. Holle F and Holle GE: Selective proximal vagotomy and pyloroplasty. Springer, Berlin, pp18-94, 1980.

77. Holle GE: Langzeituntersuchungen der Fundusschleimhaut beim Gastroduodenalulcus nach SPV (selective proximale vagotomy) und Pyloroplastic. Z Gastroenterol 16: 57-65, 1978.

78. Holle GE, Auerbach U, Hoeck H and Holle F: Longterm examination of the antrum mucosa pre and postselective proximal vagotomy and pyloroplasty in gastroduodenal ulcer. Surg Gynec Obstetr 160: 211-219, 1985. 
79. Holle GE, Buck E, Pradayrol L,Wünsch E and Holle F: Behavior of somatostatin i.r. D cells in the gastric mucosa before and after selective proximal vagotomy and pyloroplasty in treatment of gastric and duodenal ulcer. Gastroenterology 89: $731-745,1985$

80. Lehy R, Willems G and Yansteenkiste Y: Influence of vagotomy on parietal cell kinetics in the rat gastric mucosa. Gastroenterology 65: 764-772, 1973

81. Willems G and Lehy R: Radioautographic and quantitative studies on parietal and peptic cell kinetics in the mouse. Gastroenterology 69: 416-426, 1975.

82. Furness GB, Costa M, Murphy R, Beardsley AM, Oliver JR, Llewellyn-Smith JJ, et al: Detection and characterisation of neurotransmitter, particularly peptides in the gastrointestinal tract. Scand J Gastroenterol (Suppl) 718: 61-70, 1982.
83. Wood JD: Progress in neurogastroenterology. In: The Growth of Gastroenterologic Knowledge During the Twentieth Century. Kirsner JR (ed). Lea \& Febinger, Philadelphia, 1994.

84. LeDouarin NM, Dupin E and Ziller C: Genetic and epigenetic control in neural crest development. Curr Opin Genet Dev 4: 685-695, 1994

85. Witzel L, Halter F, Olah AJ and Häcki WH: Effect of prolonged metiamide medication on the fundig mucosa. Gastroenterology 73: 797-803, 1977.

86. Mazzacca G, Cascione F, Budillon G, D'Agostino L and Femiano C: Parietal eell hyperplasia induced by long-term administration of antacids in rats. Gut 19: 798-801, 1978.

87. Hansky S, Stern AI, Korman MG and Wangh I: Effect of longterm cimetidine and serum gastrin in duodenal ulcer. Dig Dis Sei 24: 468-470, 1979. 